\title{
EKSISTENSI SYAHADAT DAN SHALAWAT DALAM PRESPEKTIF TAREKAT ASY-SYAHADATAIN
}

\author{
Fakhruddin \\ STAI Al-Amin Indramayu
}

\begin{abstract}
Abstrak: Setiap manusia yang mengaku dirinya sebagai seorang muslim tentu dimulai dengan pengakuan terhadap adanya Allah swt sebagai Tuhan dan Muhammad saw sebagai utusan Allah atau yang dikenal dengan istilah syahadat. Dalam jamaah tarekat asySyahadatain pun dikenal adanya syahadat sebagaimana syahadat yang ada pada tarekat-tarekat lainnya dalam Islam. Namun demikian, dalam jamaah tarekat asy-Syahadatain terdapat perbedaan dalam hal pembacaan shalawat terhadap nabi Muhammad saw. Perbedaan dimaksud adalah perbedaan dimana Shalawat yang dibaca As-Syahadatain versi pimpinan Abah Ahmad Yahya adalah: Allahumma shalli 'ala sayyidina Muhammad. Menurut kelompok Abah Ahmad Yahya mengapa mereka dalam membaca shalawat kepada Nabi Muhammad hanya membaca Allahumma shalli 'ala Muhammad, tanpa ditambahi dengan bacaan wa 'ala ali sayyidina Muhammad, tiada lain karena mereka mengikuti apa yang telah diajarkan oleh Abah Umar bin Ismail Yahya yang merupakan pendiri jama'ah As-Syahadatain dan guru mereka yang dikenal sebagai guru Syahadat bagi mereka. Kelompok Abah Ahmad bin Isma'il dalam membaca shalawat kepada Nabi Muhammad saw dengan bacaan Allahumma shalli 'ala Muhammad, dan ditambahi dengan bacaan wa 'ala ali sayyidina Muhammad,
\end{abstract}

Kata Kunci: Syahadat, Shalawat, Tarekat, Tarekat AsySyahadatain 


\section{A. Pendahuluan}

Salah satu syarat seseorang dianggap sebagai orang muslim adalah membaca syahadat (dua kalimat syahadat), yakni penyataan atau pengakuan terhadap adalah Allah sebagai Tuhan dan Muhammad saw sebagai utusan dan rasul-Nya.

Tarekat syahadatain merupakan salah satu tarekat yang ada di Cirebon. tarekat ini memiliki bacaan syahadat yang sama sepebagaimana tarekat lain dalam islam pada umumnya. Namun yang menarik adalah cara membaca shalawat kepada nabi Muhammad saw yang berbeda antara kelompok yang ada dalam tarekat syahadatain. Perbedaan cara membaca shalawat nabi inilah yang kemudian menjadikan tarekat asy-syahadatain terbagi menjadi dua kelompok/dua jamaah, yakni kelompok Abah Ahmad yahya dan kelompok Abah Ahmad bin Ismail. Kedua kelompok jamaah AsySyahadatain tersebut memiliki argument yang kuat yang menjadi dasar bagi cara mereka dalam membaca shalawat kepada Nabi Muhammad saw.

\section{B. Tarekat}

\section{Arti Tarekat}

Di Indonesia pada umumnya dan di Cirebon khususnya terdapat banyak aliran tarekat. Salah satu aliran tarekat yang terkenal di Cirebon adalah tarekat Asy-Syahadatain. Tarekat asysyahadatain tersebut mempunyai banyak jamaah baik yang berasal dari daeraah Cirebon dan sekitarnya ataupun yang berasal dari luar pulau Jawa.

Secara etimologis kata tarekat memiliki beberapa arti, diantaranya (1). Jalan, cara (al-kaifiyyah); (2). Metode, sistem (alUslub); (3). Madzhab, aliran, haluan (al-madzhab); (4). Keadaan (al-hallah). (5). Pohon Kurma yang tinggi (an-nakhlal at-tawilah). (6). Tiang tempat berteduh), tongkat payung ('amud al-mizallah). (7). Yang mulia, terkemuka dari kaum (syarif al-qaum). (8). Goresan/ Garis pada sesuatu (al-khat fi al-asy-syay). ${ }^{1}$

${ }^{1}$ Dewan Redaksi Ensiklopedi Islam, Ensiklopedi Islam 5, (Jakarta: Ikhtiar Baru, 1997), hlm. 66. 
Kata tarikat dalam Kamus Munjid berasal dari bahasa Arab al-thariqah berarti jalan, keadaan, aliran atau garis pada sesuatu. $^{2}$ Dengan demikian tarekat adalah jalan yang ditempuh oleh para sufi yang berpangkal pada syari'at, sebab jalan utama dalam bahasa Arab disebut Syari' sedangkan anak jalan disebut thariq. Kata turunan ini menunjukkan bahwa menurut anggapan para sufi, pendidikan mistik yang dikenal dengan tasawuf merupakan cabang dari jalan utama yang dikenal dengan syari'ah/hukum yang dijadikan sebagai tempat berpihak bagi setiap muslim.

Aboebakar Atjeh menerangkan bahwa tarekat memiliki arti; jalan, petunjuk dalam melakukan suatu ibadah sesuai dengan ajaran yang diturunkan dan dicontohkan oleh Nabi dan dikerjakan oleh sahabat dan tabi'in, turun temurun sampai kepada guru-guru, sambung menyambung dan rantai-merantai. ${ }^{3}$ Atau suatu cara mengajar atau mendidik, lama kelamaan meluas menjadi kekeluargaan, kumpulan yang mengikat penganut-penganut sufi yang sepaham dan sealiran guna memudahkan.

Pada perkembangan selanjutnya, dalam tarekat muncul istilah tak mungkin ada anak jalan tanpa adanya jalan utama tempat ia berpangkal; pengalaman mistik tak mungkin didapat bila perintah syari'at yang mengikat itu tak ditaati terlebih dahulu dengan seksama. ${ }^{4}$

Terkait dengan tarekat, Harun Nasution, ${ }^{5}$ menjelaskan bahwa kata tarekat berasal dari Thariqah, yaitu jalan yang harus ditempuh seorang calon sufi dalam tujuannya berada sedekat mungkin dengan Tuhan. Tarekat kemudian mengandung arti organisasi (tarekat), dan tiap-tiap tarekat mempunyai syekh, upacara ritual, dan bentuk dzikir, dan wirid sendiri. Namun, dari sekian banyak

${ }^{2}$ Louis Ma'luf, Al-Munjid Fi Al-Lughah Wa Al-'Alam, (Beirut : Dar Al-Masyrik, 1975), hlm. 465.

${ }^{3}$ Aboebakar Atjeh, Pengantar Ilmu Tarekat: Uraian-uraian tetang Mistik (Solo: Ramadhani, 1990), hlm. 67.

${ }^{4}$ Annemarie Schimmel, Dimensi Mistik Dalam Islam, Terjemahan oleh Supardi Djoko Damono dkk. Dari Mystical Dimension of Islam (1975), (Jakarta: Pustaka Firdaus, 1986), hlm. 101.

5 Harun Nasution, Falsafah dan Mistisisme dalam Islam, (Jakarta: Bulan Bintang, 1986), hlm. 89. 
ragam jenis wirid, nampaknya yang paling banyak digemari dan diamalkan tarekat, ada tiga macam lafadz wirid, yaitu: wirid istighfar, wirid shalawat, dan wirid dzikir. ${ }^{6}$

Adapun tarekat menurut pendapat J. Spencer Trimingham adalah suatu metode praktis untuk menuntun atau membimbing seseorang murid secara berencana dengan jalan pikiran, perasaan dan tindakan, terkendali terus menerus kepada suatu rangkaian dari tingkatan-tingkatan (maqamal) untuk dapat merasakan hakekat yang sebenarnya. ${ }^{7}$ Sedangkan menurut Khaja Khan, tarekat adalah menghadapnya salik ke hadapan Tuhan dengan pensucian batin. ${ }^{8}$

Dewasa ini, istilah tarekat paling tidak dipakai untuk dua hal yang secara konseptual berbeda. Pada awalnya tarekat ini merupakan paduan yang khas dari doktrin, metode dan ritual. Akan tetapi istilah ini sering juga dipakai untuk mengacu kepada organisasi yang menyatukan pengikut jalan tertentu. Dalam hal ini istilah thaifah lebih dikenal di daerah Timur Tengah lebih dari pada tarekat dalam pengertian organisasi, dengan demikian mudah bagi mereka untuk membedakan antara tarekat yang mengandung pengertian jalan, cara dengan tarekat yang mengandung arti organisasi. Akan tetapi di Indonesia istilah tarekat mengacu kepada kedua pengertian tersebut.

Dalam prespektif kalangan Muhaddisin tarikat digambarkan dalam dua arti yang asasi. Pertama, menggambarkan sesuatu yang tidak dibatasi terlebih dahulu (lancar), dan kedua, didasarkan pada sistem yang jelas yang dibatasi sebelumnya. Selain itu tarikat juga diartikan sekumpulan cara-cara yang bersifat renungan, dan usaha inderawi yang mengantarkan pada hakikat, atau sesuatu data yang benar. $^{8}$

Adapun istilah tarekat menurut pandangan L. Massignon mempunyai dua macam pengertian, yaitu: Pertama, tarekat yang diartikan sebagai pendidikan kerohanian yang sering dilakukan

${ }^{6}$ H.A. Rivay Siregar, Tasawuf : Dari sufisme klasik Ke Neo-Sufistik. (T.t : T.p, 1999), hlm. 274. Press, 973)

${ }^{7}$ Trimingham J. Spencer, The Sufi Orders in Islam (London: Oxford University hlm.20.

8 Jamil Shaliba, Al-Mu'jam al-Falsafi, Juz II, (Beirut: Dar al-Kitab, 1979), 
oleh orang-orang yang menempuh kehidupan tasawuf, untuk mencapai suatu tingkatan kerohanian yang disebut "al-maqâmat, dan al-ahwâl. Pengertian yang seperti ini, menonjol sekitar abad ke-IX dan ke-X Masehi. Kedua; tarekat yang diartikan sebagai perkumpulan yang didirikan menurut aturan yang telah dibuat oleh syekh yang menganut suatu aliran tarekat terttentu. Maka dalam perkumpulan itulah seorang syekh yang menganut suatu aliran yang mengajarkan ilmu tasawuf menurut aliran tarekat yang dianutnya, lalu diamalkan bersama dengan murid-muridnya. Pengertian yang seperti ini, menonjol sesudah abad ke IX Masehi. ${ }^{9}$

Apabila mencoba untuk melacak secara historisnya, tentang kapan dan tarekat mana yang mula-mula muncul sebagai suatu lembaga, tampaknya sulit diketahui dengan pasti. Menurut Harun Nasution, setelah Al-Ghazali menghalalkan tasawuf yang >ebelumnya dikatakan sesat, tasawuf akhirnya berkembang di dunia Islam melalui tarekat. Tarekat ialah organisasi dari pengikut sufi-sufi besar yang bertujuan untuk melestarikan ajaran tasawuf gurunya. Tarekat ini memakai suatu tempat pusat kegiatan yang disebut ribath atau zauwiyah. ${ }^{10}$

\section{Muktabarah dan Ghairu Muktabarah}

Tarekat dewasa ini telah menyebar ke berbagai daerah bahkan keberbagai pelosok negeri di Indonesia. Pada kenyatannya, tarekat seringkali dituding sebagai penyebab kemunduran umat manusia. Stigma yang demikian, seharusnya dihilangkan. Karena memang tasawuf yang positif dapat membantu manusia dalam usaha mencapai hidup hakiki untuk mendekati kebenaran mutlak. Bila ternyata ada tasawuf yang negatif, maka tidaklah bijaksana

${ }^{9}$ H.A Mustofa, Akhlak Tasawuf, (Bandung : Penerbit CV. Pustaka Setia. 1997), hlm. 281-282.

10 Harun Nasution, Perkembangan Ilmu Tasawur di Dunia Islam, dalam Orientasi Pengemhangan Ilmu Tasawuf: Proyek pemhinaan Prasarana dan Sarana Perguruan Tinggi Agama Islam/IAIN di Jakarta, (Depag RI, 1986), hlm. 24. Lihat pula Rosihon Anwar dan Mukhar Solihin, Ilmu Tasawuf, (Bandung: Pustaka Setia, 2000), hlm. 167. 
untuk menolak tasawuf secara keseluruhan. Sikap yang arif adalah memilah untuk kemudian memilih tasawuf yang positif. ${ }^{1}$

Untuk menghindari kesalahan persepsi terhadap tarekat kiranya perlu adanya pencerahan tentang uegensi tarekat sebagai media yang justru dapat mendekatkan manusia dengan Tyhannya. Jika hal ini dilakukan maka penulis yakin stigma tentang tuduhan terhadap tarekat sebagai pembawa kemunduran dan stagnasi pemikiran manusia kian lama akan semakin terkikis habis

Dari sini kiranya semakin jelas bahwa para pelaku dan para pengamal tarekat perlu mempunyai pemahaman yang benar tentang tarekat Mu'tabaroh dan tarekat Ghoiru Mu'tabaroh agar tidak terjebak pada tarekat yang salah yang tidak nyambung pada Nabi Muhammad. Awalnya Thariqah itu dari Nabi yang menerima wahyu dari Allah, melalui malaikat Jibril. Jadi, semua Thariqah yang Mu'tabaroh itu, sanad (silsilah)-nya muttashil (bersambung) sampai kepada Nabi. Kalau suatu tarekat sanad-nya (silsilah) tidak muttashil sampai kepada Nabi bisa disebut Thariqah tidak (ghoiru) Mu'tabaroh. Barometer lain untuk menentukan ke-mu'tabaroh-an suatu Thariqah adalah pelaksanaan syari'at. Dalam semua Thariqah Mu'tabaroh syariat dilaksanakan secara benar dan ketat.

Dengan pengertian ini bisa digambarkan, adanya kemungkinan banyak jalan (thariqah), sehingga sebagian sufi menyatakan, At-Turuk bi 'adâdi anfâsi al-mahlûk, yang artinya jalan menuju Allah itu sebanyak nafasnya mahluk, aneka ragam dan bermacam macam. Kendati demikian orang yang hendak menempuh jalan itu haruslah berhati hati, karena dinyatakan pula, Faminha Mardûdah wa minha maqbûlah, yang artinya dari sekian banyak jalan itu, ada yang sah dan ada yang tidak sah, ada yang diterima dan ada yang tidak diterima. Yang dalam istilah ahli tarekat lazim dikenal dengan ungkapan, Mu'tabaroh Wa ghoiru Mu'tabaroh. ${ }^{12}$

11 Azyumardi Azra, Rekonstruksi Dan Renungan Religius Islam, (Jakarta : Paramadina. 1996), hlm. 285

12 A.R. Idhamkholid, Tarekat Asyahadatain. Tipologi dan Polarisasinya, (Cirebon : Lembaga Penelitian Dan Pengabdian Kepada Masyarakat (Lp2m) Fakultas Usuluddin Adab Dan Dakwah (Fuad) Tahun 2016). 
Suatu tarekat dapat digolongkan sebagai tarekat mu'tabarah apabila tarekat dapat memenuhi kriteria berikut ini:

1. Substansi ajarannya tidak bertentangan dengan al-Qur'an dan as-Sunnah, dalam arti bersumber dari al-Qur'an dan asSunnah.

2. Tidak meninggalkan syari'ah.

3. Silsilahnya sampai dan bersambung (ittishal) kepada Rasulullah Saw.

4. Ada mursyid yang membimbing para murid.

5. Ada murid yang mengamalkan ajaran gurunya.

6. Kebenaran ajarannya bersipat universal.

Lebih lanjut, Ahmad Tafsir sebagaimana dikutip oleh Cecep $\mathrm{Alba}^{13}$ yang menyatakan bahwa tarekat yang tidak memenuhi keriteria-kriteria seperti tertulis di atas dianggap gairu mu'tabarah yakni tidak dibenarkan untuk mengamalkannya apalagi menyebarkan tarekat tersebut.

Adapun tarekat yang disebut sebagai tarekat yang mu'tabaroh menurut pendapat Shihabuddin Suhrowardi, ${ }^{14}$ harus ada silsilahnya, jelas asal-muasalnya yang mengalir sampai sekarang. Dengan demikian tarekat mu'tabarah menurutnya adalah tarekat yang berdasarkan al-Quran dan al-Hadis. Dan tarekat mu'tabaroh yaitu tarekat yang seluruh ajarannya mengambil dari ajaran Rasulallah sebagaimana yang diceritakan oleh Syeh Bushiri dalam kitab Burdah:

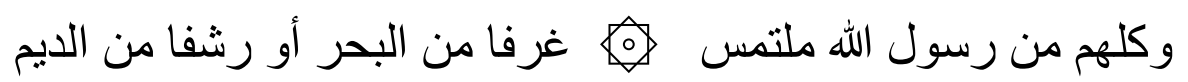

Artinya: Semua ahli tarekat mengambil dari Rasulallah. Hanya saja ada yang seperti menciduk air dari lautan atau sekedar mengambil cipratan air hujan"

Berbeda dengan konsepsi di atas, NU berpendapat bahwa pada dasarnya tidak ada diskriminasi dalam hal tarekat. Semua

13 Cecep Alba, Cahaya Tasawuf, (Bandung : CV. Wahana Karya Grafika, 2009), hlm. 19-20.

${ }^{14}$ Shihabuddin Suhrowardi, Bidayatussâlikin (Belajar Ma'rifat Kepada Allah), (Ciamis : Yayasan Serba Bakti Pondok Pesantren Suryalaya Tasikmalaya, 1971), hlm. 1. 
tarekat dianggap sah atau mu'tabarah asalkan sesuai dengan ketentuan ajaran Islam Ahl al-Sunah wa al-Jamâ'ah dan silsilahnya bersambung hingga Rasulullah SAW. tanpa terputus. Hal ini didasarkan pada penelitian teks-teks keputusan Lajnah Bahtsul Masail mulai yang pertama sampai dengan yang terakhir (19261999), tidak ada keputusan yang menyatakan adanya tarekat yang sesat atau tidak sesuai dengan Islam. Bahkan dalam Muktamar NU ke-3 di Surabaya, 29-30 September 1928, dan ke-6 di Cirebon, 2629 Agustus 1931, dinyatakan sahnya tiap tarekat asal sesuai dengan makna tarekat yang mengacu pada kitab Syarh Marâqy alUhudiyyah alâ Matn Bidâyah al-Hidâyah, yaitu:

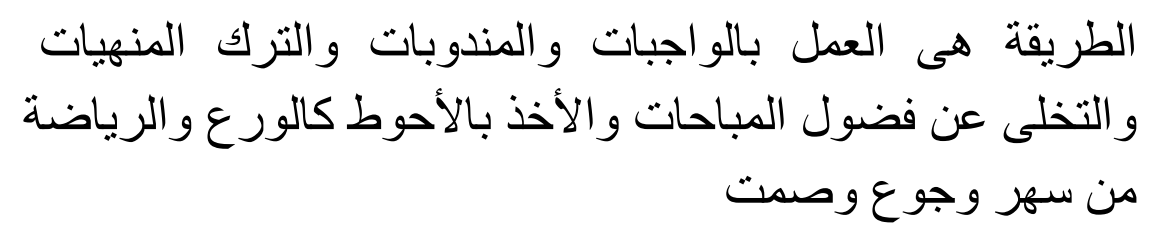

Artinya: Tarekat adalah mengamalkan semua yang diwajibkan dan yang dianjurkan, meninggalkan sетиа yang dilarang, menghindari sikap berlebihan ter-hadap hal-hal diperbolehkan dan bersikap hati-hati, seperti wara' (menghindari syubhat) dan (latihan mengekang nafsu) dengan tidak banyak tidur, lapar dan tidak banyak bicara. $^{15}$

Selanjutnya, Jam'iyyah Ahli al-Thariqah al-Mu'tabarah alNahdliyyah, sebagai Lembaga otonom NU yang mengoordinasikan tarekat-tarekat di bawah naungan NU. Nahdlatul Ulama telah melakukan kualifikasi atas thariqah-thariqah yang telah ada dan menentukan sebanyak 45 thariqah yang masuk dalam kategori mu'tabarah.

Maksud thariqah mu'tabarah disini adalah thariqah yang mempunyai sanad (mata rantai) yang tidak terputus atau

15 'Alaudin an-Naqsyabandy, Ma Huwa at-Tasawwuf wa Ma hiya at-Tariqah anNaqsyabandiyyah, (T.tp: tp., tt.), hlm., 194. Lihat juga Ahmad Zahro, Tradisi Intelektual NU: Lajnah Bahtsul Masa'il 1926-1999, (Yogyakarta : LKIS. 2004), hlm. 455. 
bersambung kepada Rasulullah Saw., dan karena itu absah untuk diamalkan. Thariqah-thariqah dimaksud menurut Said Aqil Siraj dalam bukunya yang berjudul "Tasawuf Sebagai Kritik Sosial. Mengedepankan Islam Sebagai Inspirasi Bukan Aspirasi”, Bandung : Mizan. 2006. tersebut adalah: Rumiyati, Rifa'iyah, Sa'diyah, Bakriyah, Justiyyah, Umariyyah, Alawiyyah, Abbasiyyah, Zainiyyah, Dasuqiyyah, Akbariyyah, Bayumiyyah, Malamiyyah, Ghaiyyah, Tijaniyyah, Uwaisiyyah, Idrisiyyah, Samaniyyah, Buhuriyyah, Usyaqiyyah, Kubrawiyyah, Maulawiyyah, Khalwatiyyali, Bairumiyyah, Ghazaliyyah, Hamzawiyyah, Haddadiyyah, Madbuliyyah, Sumbuliyyah, Idrisiyyah, Usmaniyyah, Syadliliyyah, Sya'baniyyah, Qalqasyaniyyah, Khadliriyyah, Syathariyyah, Khalwatiyyah, Bahdasyiyyah, Syuhriwiyyah, Ahmadiyyah, 'Isawiyyah, Thuruq alAkabir al-Awliyya', Qadiriyyah wa Naqsabandiyyah, Khalidiyyah wa Naqsabandiyyah. ${ }^{16}$

\section{Tarekat As-Syahadatain}

\section{Pendiri Tarekat As-Syahadatain}

Tarekat As-Syahadatain merupakan salah satu tarekat yang berasal dari Panguragan Cirebon. Tarekat tersebut didirikan oleh Habib Umar bin Isma'il Yahya. Dia dilahirkan tahun 1892 di desa Plumbon kecamatan Plumbon kabupaten Cirebon Jawa Barat, dan meninggal 1973 di Panguragan Wetan kecamatan Arjawinangun kabupaten Cirebon. Ayahnya bernama Habib Isma'il bin Yahya, berasal dari Tuban Jawa Timur dan ibunya bernama nyi Siti Suni'ah puteri K.H. Hasan Tuba seorang putra Wedana Plumbon Abdullah yang dikenal dengan nama Den Gowok. ${ }^{17}$

Berdasarkan catatan sejarah, dan menurut catatan silsilah keluarga yang terjaga, Habib Umar bin Isma'il Yahya yang dikenal dengan julukan Abah Umar adalah keturunan ke- 37 dari Rasulallah Muhammad. Saw. Dia merupakan pendidiri dari

16 Said Aqil Siraj, Tasawuf Sebagai Kritik Sosial. Mengedepankan Islam Sebagai Inspirasi Bukan Aspirasi, (Bandung : Mizan. 2006), hlm. 93. hlm. 1 .

${ }^{17}$ Uraian Singkat Sejarah Dan perkembangan As-Syahadatain, Tp., t.th., t.tp), 
jama'ah As-Syahadatain yang di kalangan murid-muridnya disebut sebagai guru dalam syahadat (Ilmu Tauhid). Sejak tahun 1947 panggilan Guru Syahadat ini telah menjadi panggilan umum para murid As-Syahadatain kepada Abah Umar sebagai pendiri Jama'ah As-Syahadatain. ${ }^{18}$

\section{Genealogi Tarekat/Jama'ah As-Syahadatain}

Berdasarkan catatan sejarah, genealogi munculnya tarekat As-Syahadatain ini berawal pada tahun 1937 bertempat di desa Panguragan, dimana seorang Habib Umar yang menjadi imam masjid Jami' di desanya mengadakan pengajian, sebagai pengamalan dari ilmu yang diterimanya dari pendidikan pesantren di Bobos Cirebon, Ciwedu (Kuningan), Petamburan (Jakarta) dan sebagainya. ${ }^{19}$

Dalam pengajaran pengajian yang dilakukan dalam tarekat Asy-Syahadatain meliputi berbagai materi. Adapun materi pokok pengajiannya selain materi pengajian yang biasa diajarkan di tempat pengajian tradisional saat itu, mengaji syahadat, rukun Islam pertama yang diaktualisasikan dalam amalan nyata di dalam keimanan, peribadatan dan mu'amalah untuk tujuan selamat dunia akhirat bagi pribadi, masyarakat dan bangsa/umat manusia. ${ }^{20}$

Secara harfiyah kata As-Syahadatain, memiliki arti "Dua Kalimah Syahadat" sudah diketahui umum. "As-Syahadatain" itu dipergunakan untuk nama Jama'ah Pimpinan Al-Maghfurlah Abah Umar Panguragan Cirebon. ${ }^{21}$

Salah satu alasan mendasar mengapa nama As-Syahadatain ini diambil sebagai nama jama'ah adalah karena nama itu dianggap cukup sederhana dan mengandung latarbelakang yang menurut pendapat H.A. Ismail bin Umar antara lain sebagai berikut:

Umat Islam sedunia pada umumnya sudah mengetahui tentang Lima Rukun Islam, yaitu:

1. Mengucapkan dua Kalimah Syahadah ;

${ }^{18}$ Ibid., hlm., 3

${ }^{19}$ Ibid.

${ }^{20}$ Ibid.

${ }^{21}$ H.A. Ismail bin Umar, (T.t : T.pt, T.th), hlm. 4. 
2. Menjalankan Shalat lima Waktu ;

3. Melakukan Puasa bulan Ramadhan ;

4. Mengeluarkan Zakat ;

5. Menunaikan Ibadah Haji.

Dalam Islam terdapat lima rukun Islam. Kelima rukun Islam tersebut merupakan rukun yang harus dilakukan oleh umat Islam (pada nomor 4 dan nomor 5 tentu saja bagi mereka yang mampu). Untuk melaksanakan kelima Rukun Islam itu menurut pendapat H.A. Ismail bin Umar diperlukan mengetahui semua syarat dan rukunnya. Sayang, sebagai salah satu akibat dari 350 tahun penjajahan di Indonesia ini (untuk tidak mengkambinghitamkan bangsa sendiri) sesungguhnva yang sudah banyak diketahui kaum Islam awam itu hanya syarat-rukunnya Shalat, Puasa, Zakat dan Haji saja. Sedangkan syarat-rukunnya Syahadat banyak dilupakan atau kurang peduli, itu dapat terjadi karena mungkin kebanyakan umat Islam Indonesia ini kesadaran beragamanya berdasarkan keturunan, adalah lain bagi orang/dari agama lain yang baru masuk Islam Dua Kalimah Syahadat itu jelas merupakan "Pintu Gerbang Pertama" sebelum memasuki pintu Rukun-Rukun Islam yang lain.

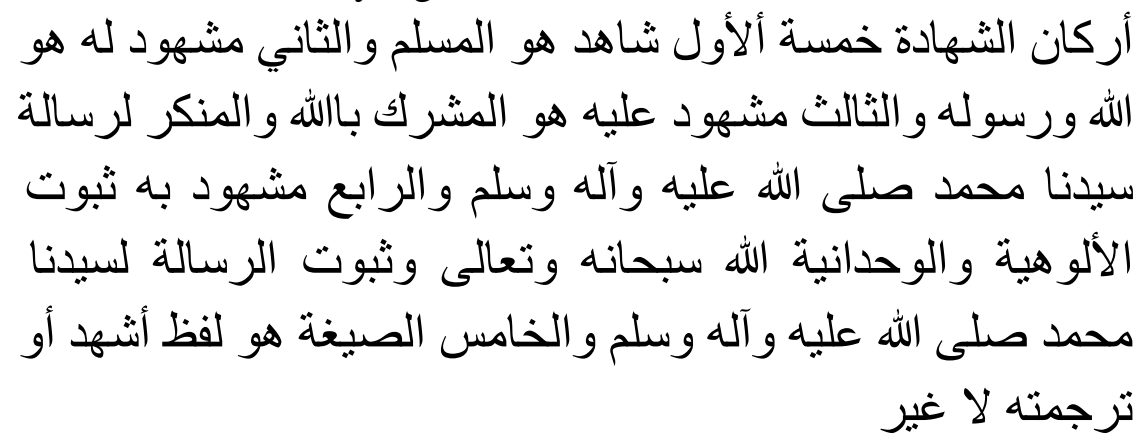

Adapun Artinya adalah bahwa Rukun Syahadat itu ada lima macam, yaitu terdiri dari:

1. Yang bersaksi, yaitu orang Islam;

2. Yang disaksikan, Yaitu Allah dan Rasul-Nya;

3. Menyaksikan tiadanya menyekutukan Allah dan memungkiri Kerasulannya Jun-jungan Nabi Muhammad S.A.W, 
4. Menyaksikan adanya, sifat Ketuhanan dan Keesaaan Allah S.W.T. dan Ketetap-annya Kerasulan bagi Junjungan Nabi Muhammad S.A.W.

5 Shighot, yaitu Kata "Aku bersaksi", atau terjemahannya tidak berlainan. ${ }^{22}$

وشروطهما ثناثة الأول العلم بمعانهما و الثانى الموالات و الثالث لفظ أشهد

Statemen di atas menunjukkan bahwa syarat sahnya mengucapkan Dua Kalimah Syahadat itu ada tiga macam, yaitu:

1. Mengetahui arti kedua Kalimah Syahadat itu;

2. Beruntun pengucapannya

3. Pakai kata "Aku Bersaksi ".

Adapun pengamalan bacaan dua Kalimah Syahadat dalam tarekat As-Syahadatain adalah didasarkan pada hadis Nabi dari Ibnu Abbas berikut ini.

عن ابن عباس رضي الله عنه أن النبي قال من داوم علي الثهادة فى الحياة الدنيا يثبت الله فى قبره إياه ويلقن إياه أثها أن لا إله إلا الله و أشهد أن محمدا رسول الله اللهم صل على على سبدنا محمد و على آله وصحبه وسلم

Artinya: Dari Ibnu Abbas r.a. menceritakan bahwa Nabi pernah bersahda: Barang-siapa terus-menerus (melanggengkan) bacaaan Syahadat selama hidupnya di dunia maka Allah akan memantapkan dalam versir orang ini pembacaannya, dan mengajari Dua Kalimah Syahadat itu padanya.

Adapun yang dimaksud dengan "Dua Kalimah Syahadat" itu adalah: bersaksi bahwa tiada Tuhan kecuali Allah, dan Aku bersaksi bahwa sesungguhnya Muhammad itu utusan Allah".

Dalam pengucapan dua kalimat sahadat tersebut tentu saja berpedoman kepada pemikiran keagamaan yang benar dan mendalam (sufi), serta kehati-hatian dari jatuhnya ke

${ }^{22}$ H.A. Ismail bin Umar, (T.t : T.pt, T.th), hlm. 5-6. 
dalam syirik dan kufur terselubung yang dapat terjadi pada setiap muslim, maka dengan niat memperbaiki atau memperbaharui keislaman dan keimanan, setiap murid memulai pengajiannya dengan membaca bersama dua kalimat syahadat. $^{23}$

Salah satu ciri menonjol dalam peribadatan pada tarekat Asy-Syahadatain adalah memperbanyak salat sunah, dzikir, doa, dan pujian asmaul husna) kepada Allah dan Rasul-Nya baik dalam bahasa Arab maupun bahasa daerah/Jawa. ${ }^{24}$

Pada prinsipnya, jama'ah As-Syahadatain, yang didirikan dan dipimpin oleh al-Maghfurlah Abah Umar menganut faham ahl al-Sunnah wa al-Jama'ah bermadzhab Imam Syafi'i (sebagaimana pada umumnya yang lazim berlaku di Pesantren-Pesantren). Karena beramalan agak menonjol dalam hal cinta kepada Nabi dan Keluarganya hingga ada Sakwasangka yang mengira bahwa Jama'ah AsySysahadatain mengikuti faham Syi'ah, itu tidak benar sama sekali.

Memang dalam hal ini mengikuti Madzhab Syafi'i sendiri ada semacam kemiripan atau persamaan cara mencintai Nabi dan keluarganya, hingga dulu pada zamannya Imam Syafi'i sendiri, ada yang menuduh mengikuti Kaum Syi'ah, sebagaimana beliau (Imam Syafi'i) menyatakan ungkapan dalam sya'irnya:
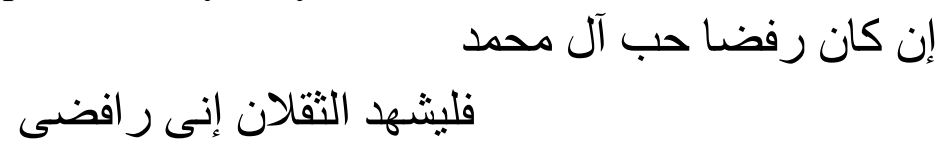

Artinya: Jika saya ada yang menuduh sebagai orang Syi'ah karena saya mencintai keluarga Nabi, maka saksikanlaholeh seluru $h$ manusia dan jin bahwa saya ini adalah penganut Syi'ah. ${ }^{25}$

${ }^{23}$ Uraian Singkat Sejarah Dan perkembangan As-Syahadatain, hlm. 2.

${ }^{24}$ Ibid.

${ }^{25}$ Dikutip dari kata sambulan Prof. Dr. Hamka dalam Buku "Al-Husein bin Ali ra Pahlawan Besar dalam kehidupan Islam pada zamannya. 
Kecintaan kepada Rasulullah dan keluarganya dapat dijadikan media untuk memupuk persahabatan dan perdamaian antar sesama umat Islam asalkan selalu dapat mengendalikan emosi/hawa nafsu, terutama untuk menengahi saudara seagama yang terlibat perselisihan, dengan tidak meninggalkan sikap tegas menghadapi kaum kuffar. Hal mana telah ditegakan dalam firman Allah Swat Al-Fath ayat 29:

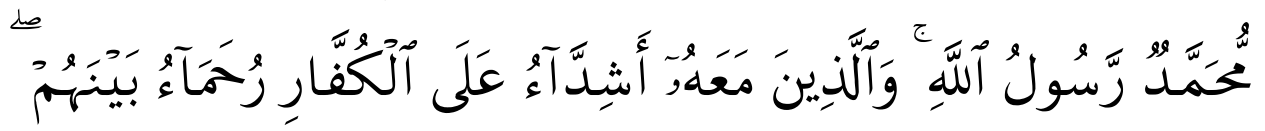

Artinya: Muhammad itu adalah utusan Allah dan orangorang yang bersama dengan dia adalah keras terhadap orang-orang kafir, tetapi berkasih sayang sesama mereka. ${ }^{26}$

\section{c. Penyebaran dan Tantangan Tarekat/Jama'ah As-} Syahadatain

Sebagai suatu tarekat, tarekat asy-Syahadatain memiliki ajaran dan doktrin. Ajaran dan doktrin tarekat/jama'ah As-Syahadatain yang didirikan oleh Abah Umar di Panguragan ini ternyata tidak hanya dikenal di wilayah Panguragan Cirebon saja, tetapi As-Syahadatain dan guru syahadatnya telah terkenal dan tersebar sampai ke Jawa Tengah, Jawa Timur, Lampung, Banjarmasin, Ambon dan Sulawesi Selatan. Malah ada sejumlah orang Aceh dan orang Malaysia belajar kepada Abah Umar. Sekarang murid-Murid As-Syahadatain telah ada di 14 provinsi di Indonesia. ${ }^{27}$

Pada awalnya, tempat pengajian Abah Umar pada masa perjuangan pernah dijadikan sebagai tempat berkumpul dan berlindung bagi para pejuang gerilya Hizbullah sabilillah, putera bangsa Indonesia yang berkhidmat untuk kepentingan bangsa dan negara. Abah Umar membantu mereka dengan memberikan supply makanan/dana yang dihimpun dan

26 (QS. Al-Fath : 29).

${ }^{27}$ Uraian Singkat Sejarah Dan perkembangan As-Syahadatain., hlm. 3. 
mendorong murid-muridnya untuk membantu memperkuat jajarannya. Dorongan yang paling besar pengaruhnya terhadap para hizbullah tersebut adalah dorongan semangat iman yang bulat dan percaya diri. Karena tindakannya ini Abah Umar sempat ditahan Belanda \pm 3 bulan. ${ }^{28}$

Dalam perjalanan waktu, ajaran As-Syahadatain yang dipimpin oleh Abah Umar ini sempat dibekukan sementara di wilayah kabupaten kuningan oleh pekuper setempat. Namun karena tidak ditemukan bukti-bukti pelanggaran baik dari segi keagamaan maupun politik pemerintahan, maka direhabilitasi dengan diizinkan membuka kembali pengajian dan madrasah Abah Umar dengan keputusan Residen Cirebon Nomor: 319/Pol.9/1963 tanggal17 Juli 1963. ${ }^{29}$

Pada perkembangan berikutnya, tarekat Asysyahadatain ini berjalan seiring dengan perjalanan sejarah bangsa Indonesia dimana terjadi peralihan kekuasaan dari kekuasaan orde lama kepada kekuasaan orde baru yang terjadi pada kekuasaan presiden Soekarno kepada presiden Soeharto yang ditandai dengan adanya supersemar. Maka dengan beralihnya pemimpin pemerintahan dari orde lama ke orde baru bagi As-Syahadatain merupakan keberuntungan yang nyata. Hal ini karena kegiatan keagamaan yang semula terasa mendapat hambatan pada masa kekuasaan orde lama, akhirnya semakin hari semakin mendapat perhatian untuk peningkatannya di masa orde baru, termasuk dalam hal ini adalah kegiatantarekat As-Syahadatain yang mendapat perhatian khusus pada masa pemerintahan orde baru. ${ }^{30}$

Sebagai tokoh yang diperhitungkan Abah Umar, ternyata pada masa kekuasaan orde baru beliau dijadikan target dan diincar oleh pemerintah untuk bergabung dengan Golkar. Namun ternyata Abah Umar tidak merespon ajakan tersebut, bahkan menolak untuk bergabung dengan partai politik. Namun diluar dugaan, bahwa kelompok jamaah yang

${ }^{28}$ Ibid.,

${ }^{29}$ Ibid., hlm., 5.

${ }^{30}$ Ibid., hlm., 5 
dipimpin Abah Umar ini menyetujui ajakan Pak Soeharto untuk memenangkan Gokar dalam pemilu 1971 dengan bergabung dalam GUPPI setelah Jendral Soedjono Hoemardhani mengadakan pendekatan dengan Abah Umar dan menceritakan bahwa orde baru akan menghilangsirnakan PKI secara konsekwen dari bumi Indonesia. ${ }^{31}$

Hal yang sungguh tidak pernah terduga sebelumnya, bahwa ternyata setelah pemilu 1971, suatu pemberian yang tidak pernah dijanjikan sebelumnya, putera. Abah Umar yaitu H.A. Ismail bin Umar diangkat sebagai anggota MPR RI dan berakhir pada tahun 1982. Demikian pula, pada tingkat daerah duduk pula pimpinan As-Syahadatain pada masa itu yaitu A. Ahmad Yahya dan Ayip Abdurrahman pada FKP DPRD Kabupaten Cirebon. ${ }^{32}$

Kepemimpinan kharismatik Abah Umar sebagai sosok pemimpin tarekat As-Syahadatain berakhir setelah ia meninggal dunia pada tahun 1973 yakni sewaktu Abah Umar melakukan salat Duha. Karena Abah Umar wafat secara mendadak, maka seakan-akan pengajian yang ditinggalkan belum memiliki kesiapan untuk melanjutkan. Selama dua tahun mengalami masa stagnan. Maka setalah itu muncul ide untuk melakukan Musyawarah Besar (Mubes) untuk melanjutkan kepemimpinan Abah Umar. Dengan Mubes itu dibentuklah organisasi jamaah As-Syahadatain sebagai suatu organisasi kemasyarakatan yang mengatur kepentingan pengajian dan warga As-Syahadatain. Selain program yang diperluas, ditetapkan aspirasi politik warga As-Syahadatain kepada Golkar dan ditetapkan H.A. Ismail bin Umar sebagai Ketua Umum, dan Drs. A. Halim Paletehan sebsgai Sekretaris Umum organisasi. Ini merupakan hasil keputusan Mubes I yang diadakan pada tahun 1976. Mubes II dilaksanakan tahun 1980, sekolah formal Ibtidaiyyah, Tsanawiyah dan Aliyah semakin ditingkatkan di pondok

${ }^{31}$ Ibid.,

${ }^{32}$ Ibid., hlm., 6 
pesantren As-Syahadatain Munjul Cirebon sebagai proyek DPP. Mubes III diadakan tahun 1986 diantara hasilnya adalah Keberadaan pesantren semakin dikembangkan, diantaranya pondok pesantren As-Syahadatain AlMusyahadah Imam Bonjol di Mayang Taurai Koto Baru Sawahlunto Sijunjung Sumatera Barat. Dalam hal ini hubungan As-Syahadatain dengan Golkar semakin baik dan semakin mesra. Hasil keputusan tentang personalia kepemimpinan Pusat Jamaah As-Syahadatain hasil Mubes I, II, dan III dapat dilihat pada halaman lampiran. ${ }^{33}$

Perputaran kepemimpinan tarekat Asy-syahadatain terus berjalan dengan baik. Pada perkembangan selanjutnya, berdasarkan hasil Mubes I yang memimpin jamaah AsSyahadatain adalah Abah Ismail bin Umar. Demikian menurut hasil Mubes II dan III maka ditetapkanlah Abah Ismail bin Umar sebagai pemimpin jama'ah tarekat Asysyahadatain. $^{34}$

\section{Shahadat dan Shalawat dalam tarekat Asy-Syahadatain.}

Baik As-Syahadatain pimpinan Abah Ahmad Yahya maupun As-Syahadatain pimpinan Abah Ahmad bin Ismail memiliki sahadat, doktrin, amalan dan ajaran serta aurad (wiridanwiridan) yang sama. Tetapi keduanya mempunyai perbedaan dalam hal pembacaan shalawat.

Perbedaan terjadi dalam hal pembacaan shalawat antara dua kelompok As-Syahadatain ini dimana kelompok Abah Ahmad Yahya hanya membaca Allahumma shalli 'ala Muhammad, sedangkan kelompok Abah Ahmad bin Ismail dengan menggukan tambahan bacaan wa 'ala ali sayyidina Muhammad, tentu dilatarbelakangi oleh konsep dan filosofis yang berbeda pula. (Perbedaan pembacaan shalawat ini bisa dilihat pada buku aurad mereka masing-masing).

\section{Pimpinan Abah Ahmad Yahya}

${ }^{33}$ Ibid., hlm. 8-10.

${ }^{34}$ Lihat Susunan Personalian hasil Mubes II dan III yang masih mencatat Abah Ismail bin Umar sebagai pemimpin jamaah As-Syahadatain. 
Shalawat yang dibaca As-Syahadatain versi pimpinan Abah Ahmad Yahya adalah:

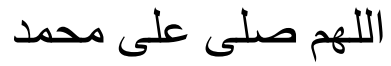

Menurut kelompok Abah Ahmad Yahya mengapa mereka dalam membaca shalawat kepada Nabi Muhammad hanya membaca Allahumma shalli 'ala Muhammad, tanpa ditambahi dengan bacaan wa 'ala ali sayyidina Muhammad, tiada lain karena mereka mengikuti apa yang telah diajarkan oleh Abah Umar bin Ismail Yahya yang merupakan pendiri jama'ah As-Syahadatain dan guru mereka yang dikenal sebagai guru Syahadat bagi mereka. ${ }^{35}$

Tarekat Asy-Syahadatain versi Abah Ahmad Yahya jelas merupakan tarekat/jama'ah Asy-Syahadatain yang mengikuti apa yang telah dilakukan oleh pendiri atau guru tarekat/ jama'ah in yakni Abah Umar bin Ismail Yahya.

Keikutan Abah Ahmad Yahya ini bisa jadi sebagai wujud dari salah satu bentuk penghormatan seorang murid terhadap ajaran mursyidnya. Hal ini -dalam konteks tarekatbisa dipahami sebagai suatu yang wajar jika murid mengikuti apa-apa yang telah diajarkan oleh mursyidnya.

\section{Pimpinan Abah Ahmad bin Ismail}

Shalawat yang dibaca As-Syahadatain versi pimpinan Abah Ahmad bin Ismail adalah:

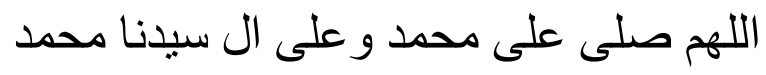

Kelompok Abah Ahmad bin Isma'il dalam membaca shalawat kepada Nabi Muhammad saw dengan bacaan Allahumma shalli 'ala Muhammad, dan ditambahi dengan bacaan wa 'ala ali sayyidina Muhammad, tiada lain karena mereka berpedoman pada pemikiran dan filosofis sebagai berikut:

35 Wawancara dengan Abah Hasan menantunya Abah Ahmad Yahya hari Minggu tanggal 9 Januari 2011. Di Kantor As-Syahadatain Versi Abah Ahmad Yahya. Lihat A.R. Idhamkholid, Tarekat Asyahadatain. Tipologi dan Polarisasinya,(T.t: T.pt, 2010, hlm. 210. 
1. Ketika Nabi masih hidup para sahabat memanggil nabi dengan Muhammad, tetapi setelah Nabi wafat memanggil Nabi dengan sebutan Sayyidina Muhammad. Hal itu dilakukan semata-mata karena mereka menghormati Nabi Muhammad. ${ }^{36}$

2. Melaksanakan Hasil musyawarah kiyai Munjul di Citemu Mundu tentang bacaan $W a$ 'Ala ali, Sayyidina sebagai bentuk penghormatan kepada Nabi dan Ahl-Bait. ${ }^{37}$

3. Hadis Nabi tentang Tsaqolain.

$$
\text { إنى نارك فيكم الثقلين كتاب الله و عترنى }
$$

Artinya: Kutinggalkan kepada kalian dua bekal: Kitabullah dan turunanku (Al-Hadis dikutip dari K.H. Abdullah bin Nuh. 1987: 22)

Syeikhul Islam Ibnu Taimiyyah (Tt:163) dalam bukunya yang berjudul "Risalatul-Furqan", mengatakan sebagai berikut:

"Yang dimaksud Hadits 'Tsaqalain' ialah sabda Nabi s.a.w.: 'Kutinggalkan kepada kalian dua bekal, Kitabullah...' Kemudian beliau mewasiatkan supaya semua kaum Muslimin berpegang teguh padanya. Beliau lalu melanjutkan: ...'Dan keturunanku, ahlu bait-ku. Kalian kuingatkan kepada Allah mengenai keturunanku, ahlu bait ku'... . diulang tiga kali dan seterusnya...."

Ibnu Taimiyyah (Tt : 297) dalam bukunya yang berjudul "Al-Washiyyatul-Kubra" menerangkan sebagai berikut:

"... Para anggota keluarga rasulullah s.a.w. mempunyai beberapa hak yang wajib dipelihara sebaik-baiknya. Allah telah memberi hak kepada

${ }^{36}$ Wawancara dengan Abah Ahmad bin Ismail, dan Abah Ahmad bin Ismail. Pada hari Minggu tanggal 9 Januari 2011 di rumahnya Abah Ahmad bin Ismail. Lihat A.R. Idhamkholid. Tarekat Asyahadatain. Tipologi dan Polarisasinya, 2010, hlm. 436.

${ }^{37}$ Wawancara dengan Abah Ahmad bin Ismail, dan Abah Ahmad bin Ismail. Pada hari Minggu tanggal 9 Januari 2011 di rumahnya Abah Ahmad bin Ismail. Lihat A.R. Idhamkholid, Tarekat Asyahadatain. Tipologi dan Polarisasinya, (T.t: T.pt, 2010), hlm. 436. 
mereka untuk menerima bagian dari seperlima ghanimah (jarahan perang) dan Allah telah memerintahkan umat Islam menyampaikan shalawat kepada mereka bersama shalawat yang disampaikan bersama Rasulallah saw. ${ }^{38}$

Mengenai Hadits Tsaqalain, para ulama mengatakan: Hadits tersefaut dinamakan "Hadits Tsaqalain" (Hadits Dua Bekal) mengingat besarnya persoalan yang terkandung di dalamnya. Ibnul-Atsir dalam kitabnya, "An-Nihayah", mengatakan: Setiap hal yang amat penting dan sangat berharga dapat dinamakan "tsaqal". Dinamakan "Hadits Tsaqalain" mengingat besarnya nilai dan untuk lebih menekankan betapa penting persoalan yang menjadi kandungan Hadits tersebut. Di dalam Kamus, "tsaqal" berarti sesuatu yang sangat berharga dan diperlukan sebagai bekal dalam perjalanan jauh. (K.H. Abdullah bin Nuh. 1987: 22)

4. Hadis Nabi tentang perintah untuk tidak membaca shalawat buntung.

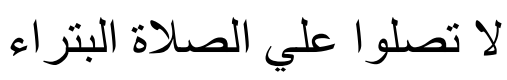

Artinya: Janganlah kamu bershalawat untukku dengan "shalawat buntung" para sahabat bertanya apakah yang dimaksud dengan "shalawat buntung" ?. Rasulullah bersabda:

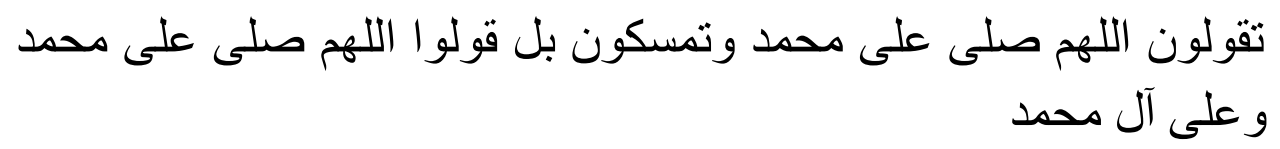

Artinya: Kalian mengucapkan "Ya Allah, limpahkanlah shalawat kepada Mu-hammad, lalu kalian berhenti disitu, tetapi ucapkanlah : Ya Allah limpahkanlah shalawal kepada Muhammad dan kepada keluarga Muhammad. ${ }^{39}$

${ }^{38}$ Lihat K.H. Abdullah bin Nuh. 1987, hlm. 33-34.

${ }^{39}$ Mahmud Syarqawiyah. Tt., hlm., 21. Lihat juga K.H. Abdullah bin Nuh. 1987. hlm. 35 . 
Syeikhul Islam Ibnul-Qayyim Al-Jauziyyah dalam bukunya yang berjudul "Jala'ul-Afham" halaman 138 menerangkan adanya empat macam faham mengenai makna "aal Muhammad s.a.w." Faham yang pertama terbagi menjadi tiga penafsiran, yaitu:

a. Penafsiran yang mengatakan, bahwa "aal Muhammad s.a.w." ialah anak-cucu keturunan Bani Hasyim dan anak-cucu keturunan Bani Mutthalib. Ini adalah madzhab Syafi'i dan Ahmad bin Hanbal, berdasarkan riwayat-riwayat Hadits yang.dikemukakan oleh dua orang Imam tersebut.

b. Penafsiran yang mengatakan, bahwa "aal Muhammad s.a.w." ialah khusus anak-cucu keturunan Bani Hasyim. Ini adalah muadzhab Imam Abu Hanifah, berdasarkan pendapat Abul-Qasim, sahabat Imam Malik.

c. Penafsiran yang mengtakan, bahwa "aal Muhammad s.a.w." ialah semua orang dari silsilah Bani Hasyim ke atas dan ke bawah hingga anak-cucu Ghalib. Penafsiran ini berdasarkan pendapat Asyhab, sahabat Imam Malik juga, sebagaimana yang dikatakan oleh penults buku "Al-Jawahir", dan oleh Al-Lakhmiy dalam buku "AtTabashshur", tetapi ia tidak mengatakan bahwa pendapat itu berasal dari Asyhab.

Tiga macam penafsiran tersebut di atas semuanya menetapkan, bahwa "aal Muhammad s.a.w." ialah mereka yang diharamkan menerimar shadaqah.

Faham yang kedua ialah yang mengatakan, bahwa "aal Muhammad saw" ialah anak-cucu keturunan Rasulullah s.a.w., khususnya para isteri beliau. Hal itu diriwayatkan oleh Ibnu 'Abdul Birr di dalam buku "AtTamhid", dan berdasarkan sebuah Hadits yang diriwayatkan oleh Imam Malik berasal dari Nu'aim Al-Mujmar, dan Hadits-hadits lainnya lagi; yang semuanya menerangkan bahwa Rasulullah s.a.w. sering berdoa: 
Artinya: "Ya Allah, limpahkan shalawat kepada Muhammad, kepada aal Muhammad, kepada para isteri dan keturunan Muhammad".

Para pendukung faham yang kedua itu mengatakan, bahwa ucapan Rasulullah s.a.w. tersebut merupakan penafsiran makna "aal Muhammad s.a.w." yang berarti para isteri dan anak-cucu keturunan beliau. Lebih jauh mereka mengatakan, jika seseorang bertemu dengan seorang isteri Rasulullah s.a.w. atau salah seorang anak-cucu -keturunan beliau, ia boleh mengucapkan:

Artinya: "Allah melimpahkan shalawat kepada anda". Dan jika tidak langsung bertemu, bolehlah ia mengucapkan:

Artinya: "Allah melimpahkan shalawat kepadanya".

Akan tetapi ucapan tersebut tidak boleh dialamatkan kepada orang-orang selain para isteri Rasulullah s.a.w. dan anak-cucu keturunan beliau.

Mereka mengatakan juga, bahwa kata "aal" atau kata "ahlu" (keturunan dan keluarga) mempunyai arti yang sama, yakni anak-cucu keturunan seseorang dan keluarga seseorang adalah sama artinya, yaitu para isteri dan anakcucu keturunannya. Pengertian itu di dasarkan pada Hadits tersebut di atas.

Faham yang ketiga mengatakan, bahwa makna "aal Muhammad s.a.w." ialah semua pengikut Nabi Muhammad s.a.w. hingga datangnya hari kiyamat. Hal itu dikemukakan oleh Ibnu 'Abdul Birr dan sementara ulama berdasarkan pernyataan Jabir bin 'Abdullah, sebagaimana disebut riwayatnya oleh Al-Baihaqiy, Sufyan Ats-Tsauriy dan lainlain. Beberapa sahabat Imam Syafi'i pun berpendapat seperti itu, sebagaimana yang dikatakan oleh Abu Toyyib At-Thabariy dalam syarahnya, kemudian dibenarkan oleh Syeikh Muhyiddin An-Nawawiy dalam kitab "Syarah Muslim", dan diperkuat oleh Al-Azhariy. 
Adapun faham yang keempat ialah yang mengatakan, bahwa yang dimaksud dengan "aal Muhammad s.a.w." adalah semua orang yang bertakwa di kalangan ummat Muhammad s.a.w. Hal ini dikemukakan oleh Al-Qadhi.Hisain dan Ar-Raghib bersama jama'ahnya. ${ }^{40}$

\section{Kesimpulan}

Tarekat Asy-syahadatain merupakat salah satu tarekat besar yang ada di Cirebon. Tarekat ini memiliki dua kelompok dengan pimpinannya masing-masing. Adanya dua kelompok jamaah dalam tarekat Asy-Syahadatain ini terjadi karena adanya perbedaan dalam hal membaca shalawat kepada nabi Muhammad saw. Namun demikian, kedua kelompok jamaas asy-Syahadatain tersebut yakni baik As-Syahadatain pimpinan Abah Ahmad Yahya maupun AsSyahadatain pimpinan Abah Ahmad bin Ismail memiliki sahadat, doktrin, amalan dan ajaran serta aurad (wiridan-wiridan) yang sama. Jadi perbedaan yang ada dalam dua kelompok jamaah tarekat Asysuahadatain tersebut hanya dalam hal dalam hal pembacaan shalawat. Kepada nabi Muhammad saw.

Perbedaan pembacaan shalawat antara dua kelompok AsSyahadatain tersebut adalah kelompok Abah Ahmad Yahya hanya membaca Allahumma shalli ala Muhammad, sedangkan kelompok Abah Ahmad bin Ismail dengan menggukan tambahan bacaan wa 'ala ali sayyidina Muhammad, saw. Perbedaan tersebut tentu saja dilatarbelakangi oleh konsep dan filosofis yang berbeda pula dengan argumen masing-masing yang kuat.

${ }^{40}$ K.H. Abdullah bin Nuh, 1987, hlm. 42-44 


\section{DAFTAR PUSTAKA}

'Alaudin an-Naqsyabandy. Ma Huwa at-Tasawwuf wa Ma hiya atTariqah an-Naqsyabandiyyah. T.tp: tp., tt.

A.R. Idhamkholid. Tarekat Asyahadatain. Tipologi dan Polarisasinya. Cirebon : Lembaga Penelitian Dan Pengabdian Kepada Masyarakat (Lp2m) Fakultas Usuluddin Adab dan Dakwah (Fuad) Tahun 2016 Aboebakar Atjeh, Pengantar Ilmu Tarekat: Uraian-uraian tetang Mistik. Solo: Ramadhani, 1990.

Ahmad Zahro. Tradisi Intelektual NU: Lajnah Bahtsul Masa'il 19261999. Yogyakarta : LKIS. 2004.

Annemarie Schimmel, Dimensi Mistik Dalam Islam, Terjemahan oleh Supardi Djoko Damono dkk. Dari Mystical Dimension of Islam. Jakarta: Pustaka Firdaus, 1986.

Azyumardi Azra. Rekonstruksi Dan Renungan Religius Islam. Jakarta : Paramadina. 1996.

Cecep Alba,. Cahaya Tasawuf. Bandung : CV. Wahana Karya Grafika. 2009.

Dewan Redaksi Ensiklopedi Islam. Ensiklopedi Islam 5. Jakarta: Ikhtiar Baru. 1997. H.A Mustofa. Akhlak Tasawuf. Bandung : Penerbit CV. Pustaka Setia. 1997.

H.A. Ismail bin Umar., Tt:

H.A. Rivay Siregar, Tasawuf : Dari sufisme klasik Ke Neo-Sufistik. 1999

Hamka "Al-Husein bin Ali ra Pahlawan Besar dalam kehidupan Islam pada zamannya.)

Harun Nasution, "Perkembangan Ilmu Tasawur di Dunia Islam", dalam Orientasi Pengemhangan Ilmu Tasawuf: Proyek pemhinaan Prasarana dan Sarana Perguruan Tinggi Agama Islam/IAIN di Jakarta, (Depag RI, 1986)

Harun Nasution, Falsafah dan Mistisisme dalam Islam. Jakarta: Bulan Bintang, 1986.

Jamil Shaliba, Al-Mu'jam al-Falsafi, Juz II, Beirut: Dar al-Kitab, 1979.

K.H. Abdullah bin Nuh. 1987

Louis Ma'luf. Al-Munjid Fi Al-Lughah Wa Al-'Alam. Beirut : dar AlMasyrik. 1975.

Mahmud Syarqawiyah. Tt 
Rosihon Anwar dan Mukhar Solihin, Ilmu Tasawuf, (Bandung: Pustaka Setia, 2000.

Said Aqil Siraj. Tasawuf Sebagai Kritik Sosial. Mengedepankan Islam Sebagai Inspirasi Bukan Aspirasi. Bandung : Mizan. 2006.

Shihabuddin Suhrowardi. Bidayatussâlikin (Belajar Ma'rifat Kepada

Allah). Ciamis : Yayasan Serba Bakti Pondok Pesantren Suryalaya Tasikmalaya. 11971.

Trimingham J. Spencer, The Sufi Orders in Islam. London: Oxford University Press.1973.

Uraian Singkat Sejarah Dan perkembangan As-Syahadatain. Tp., t.th., t.tp . 